\title{
Development of Modesty Based Learning Design at Anugrah Sayang Ibu Padang Pariaman District
}

\author{
$1^{\text {st }}$ Zulmirawati* \\ Early Childhood Education Program, \\ Faculty of Science Education, Padang, Indonesia \\ zulmirawatiimut2017@gmail.com
}

\begin{abstract}
This research is motivated by the language used by children not in accordance with the order of politeness, there are still many children who speak rude and disrespectful both with the teacher and other people, children can not distinguish how to talk to adults and peers. The purpose development is to produce a courtesy-based learning design for children aged 5-6 years that are valid, practical, and effective. This type of research is development research. This study uses a 4-D model consisting of 4 stages, namely defining, design, development, and dissemination (distribution). The instrument for collecting data in this study consisted of questionnaires to test validity and practicality. To test effectiveness, use the observation sheet. Based on the results of the validity test, the design of politeness-based learning by experts, obtained an overall average
\end{abstract}

\section{INTRODUCTION}

Early childhood education is part of the achievement of the goals of national education, as stipulated in [1] Law No. 20 of 2003 on national education systems mentioned that education is a conscious and deliberate effort to create an atmosphere of learning and the learning process so that learners are actively developing the potential for him to have the spiritual power of religion, self-control, personality, intelligence ahlak noble, and the skills required by herself, community, nation and society. To achieve the goal of education aspects of child development should be developing well. Education in early childhood education is very important for children in the future. The quality of the experience acquired in early childhood children would make more meaningful period to achieve of $91 \%$ according to the very valid category, the results of testing the practicality of teacher responses obtained an overall average yield of $\mathbf{8 8} \%$ categories is very practical too. For effective learning, learning design that is seen from the language development sheet learned by the teacher, the results of the development aspect observation sheet developed by the teacher, obtained $85 \%$ who depend on the very effective category. From the assessment of learning design results that are expected to increase children's language development. Based on these results, it was concluded that the design of learning based on politeness speaks to children valid, practical, and effective

Keywords-Learning Design, Modesty in Early Childhood Language

[2]. Early childhood education is also an organized education before entering primary education [3]. At this early age humans have a uniqueness that needs to be noticed by adults because early childhood is very important for the cultivation of moral values, cultural and other [4].

Humans as individuals and social beings in daily life can not be separated from others. Realizing this social life that is in need of the means to foster cooperation with other people, namely language. It is relevant to think [5] which is the language used to communicate or interact in a speech in public, it is clear that language as a communication tool can not be separated from the men because through the mutual human language can convey information and express ideas or ideas. 
Language is a very important tool in carrying out activities of social life. The function of early childhood language is to develop the intellectual skills and basic abilities of children [6] explains the function of the development of language skills for young children include as a means to: a) communicate with the environment; b) develop the intellectual abilities of children; c) develop the expression of the child; d) express feelings and thoughts to others. In addition, the language also has a major role in communication. Communication is done expected to qualify acceptability between speaker and hearer. The communication links that do are expected to be understood between speaker and hearer. Therefore, the importance of the role of language the language is very useful in various domains of life.

Communicate well, in fact, can not be separated from ethical language that can be called with politeness. Politeness is essentially reviewing the language spoken utterances, someone, to the hearer [7]. Politeness aims to create harmony communicate. Selection of words, sentences or utterances politely expected not to offend the audience. Politeness not only can make a good language but also can smooth the wearer. Thus it is clear that the use of language descent into demands in communi cation.

Politeness is reflected in the way of commu nicating by sign language verbal or ordinances. When communicating, we are subject to cultural norms, not merely convey the idea that he thinks. Procedures for speaking shall be in accordance with the cultural elements that exist in the community residence and is used to communi cate. If the ordinances speaking person is not in accordance with cultural norms, then he will get a negative value. For example, disrespectful, arrogant, imperious even [8].

Modesty in speaking at community and school environment are very important and need to be nurtured la early age, due to speak in a polite communication can reflect a person's character and affects a person in living life. In line with [9], politeness in communication need to be developed from an early age due to speak politely to keep the value of ourselves as social beings, who can not live alone without the help of others.

Research result [10] the results showed that all parents agreed to teach the language of courtesy to their children in the family environment based on several reasons. First, the family is the first place for children to learn about modesty. Second, teach the language of decency in children is one way to preserve our culture and the third, courtesy teach the language to children can make them a lot of disputes. Courtesy language teaching to children should be done through refraction, teaching, control and modelling. In line with the research [11]. This research mainly focuses on the investigation of teacher politeness linguistics when interacting with students, student politeness linguistics, while interacting with teachers, politeness linguistics students while interacting with their peers during the learning process in the classroom, how teachers shape students' politeness linguistics in the classroom, and how to develop students' linguistic politeness intelligent character. Research results declared the establishment of linguistic politeness in speaking can develop students intelligent character from start to finish and learning activities.

Based on our analysis through observation and interviews were done on 11-13 September with the business, teachers and parents guardians Anugrah Kindergarten Loving Mother (ASI) in Padang Pariaman Regency, it is known that there are still many children who speak harshly with teachers and parents, children may not know how to speak good manners, children can not distinguish how to talk to people who are older and with peers.

To overcome this problem, researchers want to create a learning design politeness early childhood. The design is designed in accordance with the child's developmental level. According to [12]instructional design is the process for deciding the appropriate teaching methods to bring about change knowledge and skills in learning material. In line with [13] instructional design is the work procedures used in the learning process so that learning can be conducted well and produce a good output. The purpose of this study is to develop children's 
instructional design politeness valid, practical, and effective.

\section{METHOD}

This type of research is the development research (research and development) to develop a new product or particular product enhance ments and test the validity, practicalities and effectiveness of the product [14]. Products to be gained in the study of development that instructional design politeness early childhood. Based on the explanation above, it developed instructional design politeness valid, practical, and effective for early childhood. Development model used in this study is the 4-D model of development put forward by the [15]. 4-D model of the development consists of four stages: description (define), design (design), developt (develop), and dissemination (disseminate).

The definition phase (define)

Definition phase is the stage for establishing and defining the terms of the learning. In determining and setting out the terms of learning begins with analyzing the goals and limits of the material that will be developed devices. This stage aims to define learning objectives contained in the kindergarten curriculum on environmental themes. There are three steps of activities undertaken in this phase are: curriculum analysis, requirements analysis, and analysis of children.

The design phase (design)

The objective of this scheme is to design learning to be politeness based early childhood to develop linguistic intelligence of children in speech. In accordance with the indicators and learning objectives have been determined. This design planning process as follows: analyze all subjects in all fields developing, designing indicators that correspond to the activities in the field of development, and create a learning design book.

Development stage (develop)

The aim of the development phase is to produce a valid, practical and effective learning design model. This stage includes the validation of the learning design model by experts that aims to get input by several experts on the overall contents of the material contained in the design of the learning design that was developed, after which a practicality test is conducted to see whether the design book is practical for the teacher. In addition to testing the practicality of learning design, effectiveness testing is also carried out so that it can find out whether the learning design book can improve children's language development or not.

The development phase (disseminate)

This stage is the stage of use learning design that has been developed in other subjects, such as in other schools. The aim is to test the effectiveness of using the learning design in subjects different. At this development phase will be done next test on a limited scale towards learning design which has been revised based on previous trials. At this stage in doing an evaluation of whether the learning design can be used to achieve effective in improving aspects of early childhood development.

Subject trials in this development study are kindergarten guardians Anugrah Loving Mother Pariaman Researchers chose the subject of this trial because some aspects of this research are: 1) the child's condition as needed; 2) the school environment supports adherence to the study; 3 ) teachers are not using instructional design politeness children in the learning process. The test is done to look at the practicalities and effectiveness of instructional design politeness early childhood. Data used in this study is the quantitative and qualitative data. The instrument used in this study is a validation sheet, observation sheets, questionnaires and interviews.Data analysis techniques in this study using a Likert scale and the formula percentage.

\section{RESULTS AND DISCUSSION}

Based on the stages of development proposed, the description of the research is divided into four parts: the definition phase, design phase, development phase and the deployment phase. Description of the research data is described as follows.

In the definition phase (define) include curriculum analysis, requirements analysis, and analysis of the child. The curriculum analysis is done by analyzing what the curriculum of Early 
Childhood Education (ECD) which is associated with an increased ability to speak politely in early childhood. The analysis is done by analyzing the curriculum of core competence (KI) and basic competence is there to formulate indicators. After analysis of the curriculum followed by analysis and analytical needs of children. Needs analysis aims to determine the basic issues required for the development of children in the polite language spoken through instructional design. Then the analysis of children with the aim to find out how speaking children in a school setting. In the design phase (design) is done with the design of the Weekly Lesson Plan (RPPM) and Daily Lesson Plan (RPPH). RPPH used to view and assess how implementation instructional design used. The design phase is to design instructional design book that is on the cover, material, indicators, and conclusions. The results of product design are validated by experts in the field that consists of content or material experts, linguists, and design experts to obtain valid data collection instruments. In the development phase validity test, test and test the practicalities of the effectiveness of the results can be seen in the table below.

Table 1. Results of the Test Validity Based Learning Design Language

\begin{tabular}{clcc}
\hline No. & Assessment criteria & Validity (\%) & Category \\
\hline $\mathbf{1}$ & Material aspects & $100 \%$ & very valid \\
\hline $\mathbf{2}$ & Aspects of language & $88 \%$ & very valid \\
\hline $\mathbf{3}$ & Design aspects & $85 \%$ & very valid \\
\hline & Total Average & $91 \%$ & very valid \\
\hline
\end{tabular}

Table 2. The Test Results Based Instructional Design Practicalities of Politeness

\begin{tabular}{clcc}
\hline No. & \multicolumn{1}{c}{ Indicators rated } & $\begin{array}{c}\text { Practicality } \\
\text { Percentage (\%) }\end{array}$ & Category \\
\hline $\mathbf{1}$ & User practicalities & $91 \%$ & very Practical \\
\hline $\mathbf{2}$ & Suitability Illustration & $87 \%$ & very Practical \\
\hline $\mathbf{3}$ & Language & $88 \%$ & very Practical \\
\hline $\mathbf{4}$ & Suitability time & $83 \%$ & very Practical \\
\hline & Average & $88 \%$ & very Practical \\
\hline
\end{tabular}

Table 3. Test results-based learning design effectiveness politeness children.

\begin{tabular}{clcl}
\hline No. & \multicolumn{1}{c}{ Rated Aspect } & $\begin{array}{c}\text { Practicality } \\
\text { Percentage (\%) }\end{array}$ & Category \\
\hline $\mathbf{1}$ & Can greet and answer greetings & $81 \%$ & very effective \\
\hline $\mathbf{2}$ & Speaking with sopans & $86 \%$ & very effective \\
\hline $\mathbf{3}$ & Asking for help with both & $85 \%$ & very effective \\
\hline $\mathbf{4}$ & $\begin{array}{l}\text { Saying excuse me while willing to permit } \\
\text { urination and defecation }\end{array}$ & $87 \%$ & very effective \\
\hline
\end{tabular}




\begin{tabular}{clcc}
\hline 5 & $\begin{array}{l}\text { Ask permission first when it wants to } \\
\text { borrow right toys }\end{array}$ & $88 \%$ & very effective \\
\hline $\mathbf{6}$ & $\begin{array}{l}\text { Borrowing toy friends with polite } \\
\text { language }\end{array}$ & $82 \%$ & very effective \\
\hline Average & $88 \%$ & very effective \\
\hline
\end{tabular}

Development is done in kindergarten B Anugrah Sayang Ibu which his son amounts to 15 children development based learning design politeness performed in children so that children can speak well and manners. Bookbased learning design politeness children considered valid if it has met the conditions specified. Validation of this handbook by three validators, which is an expert in his field of study, among others: material expert, content material expert, and leraning design expert. This is consistent with the explanation [16] that "can be used to test the validity of the expert opinion (judgment validity)"

Based on the results of the validation conducted by three expert validators (lecturer) states that the book-based learning design politeness children have very valid with the validity of an average of $91 \%$. The validation manuals carried out several aspects: the material, language aspects, and aspects of design. The tests were evaluated from the aspect of material with a very valid category. This means that the material in the book design is created according to the needs of teachers, the material in the manual is easy to understand, book design can broaden teachers, the truth of the substance of the material in the book fine design, book design comes with example semester program that can help teachers understand material, and the presentation of the material has been sequentially.

The results of the validation aspects of language that gained included the category of very valid. This means that the preparation is already communicative phrases used, the suitability of the preparation of the phrase used by the rules of the Indonesia spelling, the information conveyed is clear and easily understood sentences. The results obtained after the revision which is not much.
Furthermore, from the aspect of design, the result of validation included in the category of very valid. This shows that the presentation of the book design-based learning politeness child is good, systematic start the title, cover, and indicators to be achieved is appropriate, the presentation of the images are clear and compelling, the balance between the illustrations and the display, and the colours and images used interesting so can help parents and teachers to read. This is in line with [17] that the use of images in the book can attract the attention of the reader and make the reader in understanding the book.

The practicalities of the guidebook aims to look at the extent to which teachers can understand and use the book-based instructional design politeness child a good book, in addition, to meet the validity criteria should also be practical means teachers can use with ease.

The total average test results practicalities through teacher questionnaire responses showed that the book-based instructional design developed politeness children included in the category of very practical with a value of $88 \%$. These results show the design book-based learning politeness child development can help teachers implies speaking manners to children, book design can facilitate teachers to understand the character of the child, the guidebook facilitates teachers to be closer to children, illustrations appropriate to order materials and presenting easily understood sentences. Value test the practicalities of teachers is highest in ease of use of indicatorbased instructional design book politeness that is equal to $91 \%$ of children categorized as very practical.

Lowest practicalities test values are at implementation time indicator. The low value of the practicalities of the indicator is due to the 
teachers could not give a long time or focus for habituation to speak politely. Yet seen from the results of the test the practicalities of the average values obtained by $88 \%$, which is the category of very practical. So it can be concluded that the design of child-based learning politeness developed a very practical use for children aged 5-6 years.

To determine the effectiveness of the design book can be seen from the results of the observation sheet aspects of language development of children with the observation made by the teacher. From the results of observation sheets made by the teacher, the result is that aspect of language development of children developing very well this can be seen from the children are able to greet and answer greetings in a gentle manner, the child already speaks politely to the teacher and his friends, children can ask please well, the child is able to say excuse me when permission to urinate or defecate,ask permission first when it wants to borrow right toys, and children can borrow toys friends with polite language.

From the results of observation sheets, aspects of child development can be concluded that the book-based learning design politeness effective. Because children can improve aspects of language development of children aged 5-6 years with very well.

\section{CONCLUSIONS}

This study is a research-based instructional design development politeness early childhood. The process of developing these materials using 4-D models with four stages: define, design, develop, and disseminate.Based on the analysis, development, testing, and development is done,it can be concludedthat several things as follows. Produced book-based instructional design politeness children with an average of $91 \%$ category of very valid. It can be seen from the validation sheet based instructional design book politeness child validator expert. Validator of votes envisaged that developing books have been valid and can be used in the learning process.Results from testing the practicalities of book-based learning design politeness child who rated by teachers as a whole in the category of very practical. It can be seen in the average value of the practicalities of response at $88 \%$ of teachers are in the category of very practical. Illustrated books of teacher assessment based instructional design are very practical children's politeness so that easy to understand and use. Effectivelyvitas usage-based instructional design book child politeness can be seen through questionnaire aspects of language development of children aged 5-6 years were filled by teachers. The results of the questionnaire aspects of language develop ment of children with a percentage of $84 \%$ are a very effective category. Aspects of child language development be increased after a given indicator of politeness.

\section{ACKNOWLEDGMENTS}

This study will not be successful without the help of my supervisor, Mr. Dr Alwen Bentri, M. Ed and friends who always support and constructive feedback so that I can complete my research is timely. I would like to thank the lecturers and friends. I would also like to thank the head of the kindergarten Anugrah dear mother who has given me permission to examine in kindergarten milk.

\section{REFERENCES}

[1] Law No. 20 of 2003 on national education systems-Depdiknas. (2003). Undangundang RI No. 20 tahun 2003 tentang sistem Pendidikan Nasional.

[2] Eliza, D. (2013). Penerapan Model Pembelajaran Konstektual Leraning (CTL) Berbasis Centra di Taman Kanak-Kanak. XIII(2), 93-106.

[3] Suryana, D. (2013). Profesionalisme Guru Pendidikan Anak Usia Dini Berbasis Peraturan Menteri No. 58 Tahun 2009. Ilmiah, Jurnal Pendidikan, Ilmu Xiii, Volume, XIII (2), pp. 53-61. http://doi.org /http://journal.ini.ac.id/index.php/pedag ogi

[4] Rakimahwati, Y. (2012). Upaya Meningkatkan Perkembangan Moral Anak Usia Dini Melalui Mendongeng Di TK Dharmawanita. Improving the Moral Development of Early Age Children. 7(1).

[5] Chair, A. (2010). Kesantunan Berbahasa. Jakarta: Rineka Cipta. 
[6] Depdiknas. (2000). Permainan Membaca dan Menulis di Taman Kanak-Kanak. Jakarta: Depdiknas.

[7] Karunia, S. I. (2015). Kesantunan Berbahasa Guru dan Siswa dalam Pembelajaran Bahasa Indonesia di SMPNegeri 5 Jember. 4.

[8] Sumarna. (2015). Bicara Santun dan Keberhasilan Komunikasi. Seminar Nasional Prasasti II.

[9] Rois, S. S. H. (2017). Pembentukan Karakter Melalui Kesantunan Berbahasa. Prosiding Seminar Nasional PPKn III.

[10] Yenni, E., Yusriati, \& Sari, A., W. (2018). Pola Pengajaran Kesantunan Berbahasa Anak di Lingkungan Keluarga. Jurnal Tarbiyah, 16(1). https://doi.org/10.1360/ zd-2013-43-6-1064

[11] Mariani, N. (2015). Developing Students' Intelligent Character through Linguistic Politeness: TheCase of English as a Foreign Language for Indonesian Students. English Language Teaching, 9(1), 101. https://doi.org/10.5539/elt.v9n1p101
[12] Yaumi, M. (2013). Prinsip-Prinsip Desain Pembelajaran. Jakarta: Prenadamedia Group.

[13] Mudlofir, Ali. Rusydiyah, F. (2016). Desain Pembelajaran Inovatif dari Teori ke Praktik. Jakarta: PT. RajaGrafindo Persada.

[14] Sugiyono. (2009). Metode Penelitian Pendidikan Pendekatan Kuantitatif, Kualitatif, dan RED. Bandung: CV. Alfabeta

[15] Trianto (2010). Model Pembelajaran Terpadu. Jakarta: PT Bumi Aksara

[16] Riduwan. (2009). Belajar Mudah Penelitian Untuk Guru Karyawan dan Penelitian Pemula. Bandung:Alfabeta.

[17] Sanjaya, W. (2008). Perencanaan dan Desain Sistem Pembelajaran. Jakarta: Prenadamedia Group 